Xia, J. Nesbitt, J., Daley, R. Najnin, A. Litman T. and Tiwari S. (2016) A multi-dimensional view of transport-related social exclusion: A comparative study of Greater Perth and Sydney, Transport research part A: policy and practice, 94:205-221. 64 http://dx.doi.org/10.1016/j.tra.2016.09.009.

\title{
A Multi-dimensional View of Transport-related Social Exclusion: A comparative study of Greater Perth and Sydney
}

\author{
Jianhong(Cecilia) Xia ${ }^{a^{*}}$, Joshua Nesbitt ${ }^{\mathrm{a}}$, Rebekah Daley ${ }^{\mathrm{a}}$, Arfanara Najnin ${ }^{\mathrm{a}}$, Todd Litman ${ }^{\mathrm{b}}$ and Surya \\ Prasad Tiwari ${ }^{\mathrm{c}}$ \\ ${ }^{a}$ Department of Spatial Sciences, Curtin University, Kent Street, BENTLEY, Perth, WA 6102, Australia \\ ${ }^{\mathrm{b}}$ Victoria Transport Policy Institute, 1250 Rudlin Street, Victoria, BC V8V 3R7, Canada \\ ${ }^{c}$ University of Kiel, Iltisstrasse 24, 24143, Kiel, Schleswig-Holstein Germany
}

\begin{abstract}
Transport-related social exclusion is a complex issue. It can be studied from a variety of angles, be influenced by a number of factors, and affect diverse population groups. This study investigates transport-related social exclusion from a multi-dimensional view. Transport inequity was measured based on different development stages of a region using the Lorenz Curve and Gini index, and compared socio-economic characteristics, such as housing affordability, employment self-sufficiency, urban sprawl, and transport-mode share at different degrees of spatial aggregation. Two hierarchical spatial aggregation levels are used: 1) Sydney - Perth; 2) Inner - Middle - Outer sectors. Spatial gaps of transport-related social exclusion are identified for both cities and a number of policy implications are considered to provide suggestions to improve transport-related social inclusion in both cities.
\end{abstract}

Key words: Transport-related social exclusion, Gini index, urban development stages, housing affordability, and Employment self-sufficiency.

\section{Introduction}

Social exclusion (also called social inequity or injustice) refers to the obstacles that certain groups, such as those with physical or mental disabilities, low incomes or minority status, face in accessing economic and social opportunities, such as healthcare, education and employment. Social exclusion tends to be inefficient and unfair, so most communities consider social inclusion (that is, reducing social exclusion) to be an important policy goal (Lucas 2012). Integrating transport with other policies, such as affordable housing, employment selfsufficiency and urban sprawl, can help achieve social inclusion objectives (Litman 2015, Bureau of Infrastructure Transport and Regional Economics (BITRE) 2013, Currie et al. 2010, Church and Frost 1999). According to Church, Frost, and Sullivan (2000), transport-related social exclusion studies can be divided into two types based on the focus of research: category approach and spatial approach. The focus of the category approach is on the transport demand side, addressing issues such as travel patterns, attitudes and needs of particular social groups (Gaffron 2012, Shergold and Parkhurst 2012). The spatial approach emphasises the transport supply side particularly the quality of transport supply, access to public transport, and spatial gaps of transport supply based on resident's needs (Currie 2010, Ricciardi, Xia, and Currie 2015, 
Kaplan et al. 2014, Welch 2013). These studies investigate how social exclusion is related to transport supply, for whom, in what direction, where and why. Most transport-related social exclusion studies focus on a single region, from which conclusions are drawn for a specific city, at a particular development stage and for a particular dimension of the problem, such as age or income. There is a need to understand the transport inequity problem from a multi-dimensional view. This includes multi-levels of spatial scale, such as, inner urban areas, middle areas, outer areas of a city, a whole city, or even a country, multi-levels of urban development stages and a variety of factors affecting transport-related social exclusion.

The aim of the study is to use urban planning tools to conduct a systematic comparison of transport inequity from a multi-dimensional view. Transport inequity refers to transport constraints that prevent people from participating in or having access to social activities, employment, education and social services (Litman 2014). Inadequate transport supply could contribute to the social exclusion of people, especially vulnerable people, such as people who don't own a car, have a low income, older people, or people with disabilities. Transport inequity evolves based on both population density (demand side) and levels of transport services (supply side). The imbalance between demand and supply, more precisely higher demand than supply, leads to patterns of transport-related social exclusion. The research questions raised here are:

- How is transport-related social exclusion different at various levels of spatial aggregation and urban development?

- What are the factors that cause the difference in transport-related social exclusion?

In order to answer these research questions, the Lorenz Curve and Gini index were used to measure transport inequity at the various levels of urban development. We proposed two nested spatial aggregation levels:

- City level: large city (Greater Sydney - five million population) and medium city (Greater Perth - 2 million population);

- Sector level: inner, middle, and outer sectors.

The first research question was answered by a systematic comparison of transport inequity at the two levels for three cohorts: people who are don't own a car, those with a low income, and seniors. We also conducted spatial gap analysis using a supply demand matrix to identify the areas of concern for the three cohorts at the two levels. The second research question was answered by developing a conceptual framework to understand transport inequity at various levels of urban development and its relationship with a variety of factors such as housing affordability, employment self-sufficiency and urban sprawl.

\section{Related research}

\subsection{Definition of transport-related social exclusion}

Both social equity and access to transport have been the subject of extensive academic research around the world (Lucas, Tyler, and Christodoulou 2009, Currie 2010, Bocarejo et al. 2012). Transport inequity has been found to be one of the important factors leading to social exclusion (Lucas, van Wee, and Maat 2016). However, the definition of equity, as a base for measurement, changes according to the field being considered (Welch and Mishra, 2013) and is further complicated for transport distribution as it becomes more complex (Litman 2014). In order to more accurately measure transportation equity, three categories can be considered (Litman 2014): 
- Horizontal equity: focus on transport fairness through the spread of resources amongst socio-economic groups with equivalent ability and need.

- Vertical equity with regard to income and social class: focus on the spread of resources among socio-economic groups with differing ability and need.

- Vertical equity with regard to mobility need and ability: focus on fairness of the resources amongst those with special needs.

Both horizontal and vertical equity are considered throughout this research. Horizontal equity is considered with an all-inclusive analysis of where all Statistical Area Level 1s (SA1s, the smallest geographical unit for the release of Census data by the Australian Bureau of Statistics (Australia Bureau of Statisitics (ABS) 2011) are considered to be of the same importance. Equity is then tested by how well each SA1 is serviced and how this transport supply is distributed among the SA1s. Vertical equity with regard to income and social class is then considered by an analysis of the distribution of transport supply to the three socioeconomic groups. A similar approach was successfully used in a recent study by Ricciardi, Xia, and Currie (2015).

\subsection{Methods in measuring transport-related social exclusion}

Three streams of research has been developed in the area of transport-related social exclusion since the1990s (Masser, Svidén, and Wegener 1992).

The first stream defines equity and the transport-related social exclusion (Khisty 1996, Rawls 1971) and lays the theoretical foundation for this (Lucas 2006, Liu, Triantis, and Sarangi 2010, Jones and Lucas 2012, Preston and Rajé 2007). Some examples of these theories include value judgement (Khisty 1996, Sen 1997), social capital (Di Ciommo et al. 2014, Granovetter 1985), entitlement (Sen 1981, Preston and Rajé 2007), subjective well-being (Diener 2000), risk of social exclusion (Social Exclusion Unit 2001), and sense of community (Stanley et al. 2011, McMillan and Chavis 1986).

The second stream is the socio-spatial analysis of transport-related social exclusion (Blair, Hine, and Bukhari 2013, Currie 2010). At a high level, Geographic Information Systems (GIS) and spatial modelling techniques are used to explore the spatial mismatch between supply and demand, network analysis, connectivity and accessibility (Fan, Guthrie, and Levinson 2012, Manaugh and El-Geneidy 2012, Vaughan 2007, Welch 2013, Miller 2006). Then, at an applied level, social or personal network (Viry 2012), infrastructure network (Bruinsma and Rietveld 1993), transit connectivity (Kaplan et al. 2014, Mishra, Welch, and Jha 2012), and accessibility and mobility (Preston and Rajé 2007) are used as tools to measure transport-related social exclusion.

The third stream is comparative studies of transport-related social exclusion. It has been found that when comparing two geographic areas or demographic groups with comparable incomes and abilities, it would be most fair if they each receive equal annual per capita allocations of public resources, but if one area or group is economically, socially or physically disadvantaged, it should receive a greater allocation (Litman, 2014). Other models have found that not all disadvantaged groups respond the same to transport poverty, with findings suggesting households on the urban fringe and without a car adjust well to their circumstances by living close to activity centres (Currie et al., 2010). Further, Ricciardi et al. (2015) compared transport-related social exclusion between no-car households, low-income households and the elderly between Perth and Melbourne, and found that Perth had a more equal public transport service for these three groups than Melbourne.

\subsection{Variables in measuring transport-related social exclusion}


Suffering transport disadvantage is here considered to mean not being able to easily travel where and when one needs to go for, say, work, social, or recreational pursuits. A household can also be considered as suffering transport disadvantage (or transport poverty) if the cost of transport reduces the ability to pay for other basic items, or when services are severely restricted or non-existent due to, for example, distance or low passenger volumes (Currie and Delbosc 2013). Previous research indicates that lower income households will generally have fewer private vehicles, which leads to a higher reliance on public transport (Welch \& Mishra, 2013). Meanwhile, households with no car at all (including those with higher incomes) are often content with their situation and cope accordingly with the public transport available to them (Currie \& Delbosc, 2009). Another study found that people who had the greatest risk of social exclusion travelled less often and less distance, owned fewer cars and used public transport less than those who were more advantaged (Stanley et al. 2010). These studies suggest that the elderly, low-income households, and no-car households can be considered the major disadvantaged groups for this study.

Previous studies have typically considered a large range of variables in measuring transportrelated social exclusion including trip frequency, speed, distance, capacity, required transfers, land use of the transit node, accessibility, time, and cost (Welch 2013, Welch and Mishra 2013, Mishra, Welch, and Jha 2012). A large number of studies have also sought to understand the underlying process and factors affecting transport inequity, such as housing affordability (Welch 2013, Litman 2015, Dodson 2004), jobs-housing balance (Zhao, Lü, and Roo 2011, Bureau of Transport and Regional Economics [BTRE] 2007), urban sprawl (Alpkokin 2012, De Vos and Witlox 2013), transport mode share (Bocarejo et al. 2012), social capital (Schwanen et al. 2015), residential density (Buxton and Scheurer 2007) and residential segregation (Liu, Dijst, and Geertman 2015). Using a wide range of factors as these studies have done allows for a spatially distributed analysis, meaning the effects on different socio-economic groups can be analysed (Jones and Lucas 2012, Páez et al. 2010). Meanwhile, other research in the field has been conducted to understand the social exclusion and transport equity specifically for better planning and decision-making using techniques such as regression models (Páez et al. 2010), structural equation models (Currie and Delbosc 2009), spatial tools (Preston and Rajé 2007), and economic tools, such as Gini Coefficients (Delbosc and Currie 2011, Mishra, Welch, and Jha 2012).

This study seeks to address what are seen as gaps in previous research. For example, many studies and research projects been carried out regarding transport disadvantage and social exclusion issues in particular cities, such as Melbourne, Australia (Currie, 2010; Graham Currie, et al., 2010; P. G. Currie \& Delbosc, 2009; Loader \& Stanley, 2009), which have helped to develop better decision- and policy-making processes. There is, however, a lack of comparative studies about transport systems and policy from a multi-dimensional view such as multidimensional spatial aggregation levels, development stages of regions, and populations. We are also especially interested in the impact of socio-economic factors, such as housing affordability and employment self-sufficiency on transport-related social exclusion. Therefore, two Australian capital cities have been chosen for this project, Perth and Sydney. These two cities have strong geometrical differences, with Perth exhibiting a long linear sprawl along a narrow coastal plain, whereas Sydney is located in a coastal basin, bounded by mountains to the West and major inland rivers. These two cities are also at different development stages. The comparison of such spatially different cities has yet to be considered in the available literature.

\section{Methods}

The methodology used here can be broken down into four components: 
- Calculation of public transport supply in Perth and Sydney;

- Identification of areas in each city having high- and low-demand for public transport for the three transport-disadvantaged groups (the elderly, no-car households, low income households) focused on in this study;

- Identification of areas having low supply but high demand for public transport for the three groups in each city; and

- Calculation of Lorenz curves and Gini coefficients representing transport equity amongst the three.

These components are elaborated on below.

\subsection{Supply Index}

The supply of public transport to each Statistical Area Level 1 (SA1) in Perth and Sydney was measured using the supply index value, following the methodology outlined by Currie (2010). A dataset containing the SA1 boundaries for Australia was acquired from the Australian Bureau of Statistics (ABS) from which the Greater Perth and Sydney areas were defined. ABS data was also used to define urban centres and localities, which allowed the broader metropolitan areas to be broken down into inner, middle, and outer city areas. Public transport network datasets for Perth and Sydney, with the weekly number of service arrivals for each transit stop, were acquired from the Western Australia Department of Transport and Transport for New South Wales, respectively.

Calculation of the public transport supply index was broken down into several smaller steps as follows:

- The ABS spatial dataset of SA1 boundaries covers all of Australia. This dataset was clipped to the boundary of greater Perth and greater Sydney as defined by the 2011 Census.

- Walking catchments around every public transport stop location in both cities were created using a distance buffer. Sydney has some different modes of public transport compared with Perth, in that it has light-rail services in addition to the train, bus and ferry services that are available in both cities. For the purposes of this study, light-rail stations and ferry wharves were considered to have the same walking catchment size as that of train stations used in the study by Currie (2010), namely a buffer radius of 800 metres. Walking catchments for each public transport stop location were calculated by creating a buffer area around each stop depending on the type of public transport available at that stop, using the following distances:

\footnotetext{
○ Bus stops $-400 \mathrm{~m}$

○ Train stations $-800 \mathrm{~m}$

○ Light rail stations $-800 \mathrm{~m}$

- Ferry wharfs $-800 \mathrm{~m}$
}

- The overlap between transport stop walking catchments and each SA1 area were examined in order to calculate the supply index for each SA1. To calculate the supply index score, the number of service arrivals for each walking catchment overlapping an SA1 was multiplied by the percentage of the total area of the SA1 that was overlapped 
by the walking catchment. These were then summed to give the total supply index score for each SA1. The equation to calculate the supply index for a given area is given by (Currie, 2010):

$$
S I_{S A 1}=\sum_{i=1}^{n}\left(\frac{A_{B_{i}}}{A_{S A 1}} \times S L_{B_{i}}\right)
$$

where $S I_{S A 1}$ is the supply index of an SA1, $S A 1$ is the SA1 in question, $n$ is the number of transport stop walking catchments in the particular SA1, $A_{B i}$ is the square kilometre area of the walking catchment falling within the SA1, $A_{S A l}$ is the square kilometre area of the SA1, and $S L_{B i}$ is the number of weekly service arrivals for the transport stop in question.

A simple example of this is shown in Fig. 1. The SA1 in question has three transport stop walking catchments overlapping it, with transport stop A, B and C having 100, 50 and 30 service arrivals per week and overlapping 7.5\%, 10\% and 5\% of the total SA1 area respectively. The supply index for the SA1 in question is therefore equal to a value of 14, given by:

Supply Index $=(100 \times 0.075)+(50 \times 0.1)+(30 \times 0.05)=7.5+5+1.5=14$

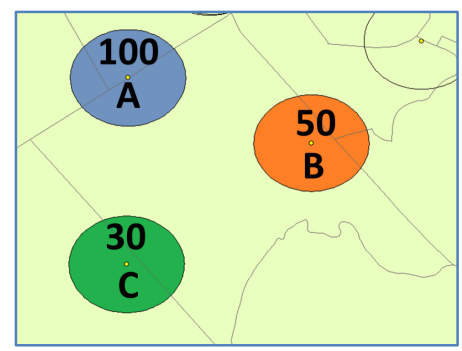

Fig. 1. Simple example of supply index for an SA1.

\subsection{Normalised Supply Index by Population by Area (NSIPA)}

While useful for comparing public transport supply within an individual city, the supply index value may lose meaning when used to compare public transport between two or more cities. This is because larger cities, such as Sydney, are likely to have higher supply index values than smaller cities, such as Perth, simply due to the fact that they have larger populations and are spread across larger geographical areas, and therefore overall transport supply needs to be higher to support greater demand. In order to more meaningfully compare transport supply between the two cities, the population and the area of a particular SA1 will be considered along with its supply index value in order to calculate a Normalised Supply Index by Population by Area (NSIPA) value, using the following equation:

$$
\begin{aligned}
N S I P A_{i} & =\frac{S I_{i}}{\left(P_{i} \times A_{i}\right)} \\
\mu_{N S I P A} & =\frac{\sum_{i=1}^{n} \frac{S I_{i}}{\left(P_{i} \times A_{i}\right)}}{n}
\end{aligned}
$$


Where, $\mu_{N S I P A}$ is the average of NSIP $A_{i}$ value; $S I_{i}$ is the supply index of SA1 $i$; $P_{i}$ is the number of population of SA1 $i ; A_{i}$ is the area of SA1 $i$.

By then grouping the resulting values into a number of classes and keeping these classes consistent across both cities, the NSIPA value will also allow easier visual comparison between Perth and Sydney in terms of public transport supply.

\subsection{Transport Supply and Demand}

The socio-economic data used in the analysis, which was required in order to identify areas in each city that have high numbers of residents falling within the three transport disadvantaged groups, was acquired from the ABS as part of the 2011 Census dataset. The following socioeconomic data was then attributed to our existing SA1 dataset:

- Percentage of elderly residents: the ratio of those over 65 years of age to the total population.

- Percentage of no-car households: the ratio of households without a car to the total number of households.

- Percentage of low income households: the ratio of households with a low income (those in the lowest $40 \%$ of weekly household incomes) to the total number of households.

Areas which were considered to have a high-demand for public transport for a particular transport disadvantaged group, for example elderly residents, were those SA1s which had a percentage of that group in the highest quartile across the city in question. Conversely, areas considered to have a low-demand for public transport were those in the lowest quartile. High and low transport supply was defined in a similar way: those SA1s which had a supply index value in the highest quartile across the city under examination were considered as high supply areas, while those in the lowest quartile were considered low supply areas.

It should be noted that this study only focused on the top and bottom quartiles of values in order to define low/high supply and low/high demand, and thus SA1s falling into the second and third quartiles of supply index values or percentage of elderly population/no car household/low income household values were classified as others.

\subsection{Identifying Areas of Concern}

Areas of high public transport demand and low public transport supply for a particular socioeconomic group can show us where transport disadvantage is highest for that group. However, areas of significant concern are considered to be those which have both a low-supply and highdemand for all three socioeconomic groups considered, as these are likely to be areas where transport-based social exclusion is at its highest.

\subsection{Lorenz Curve and Gini Coefficient}

Lorenz curves have typically been used in the field of economics to represent the distribution of income across a population. Here they have been used to examine the distribution of the public transport supply index value across the populations of Perth and Sydney in a similar fashion as was done for a study of transport equity in Melbourne, Australia (Delbosc and Currie, 2011b). In a perfectly equal scenario, $10 \%$ of the population has access to $10 \%$ of the public transport, $20 \%$ of the population has access $20 \%$ of the public transport, and so on. This is represented by the straight line shown in Fig. 2. In reality the actual distribution of public transport will be less than equal in most cases, and this is represented by the curved line in Fig. 2. The use of Lorenz curves in this study allows for a comparison of public transport equity between the three socioeconomic groups in each city and the entire population. This also enables a relative comparison between Perth and Sydney, which is a major focus of this study. 


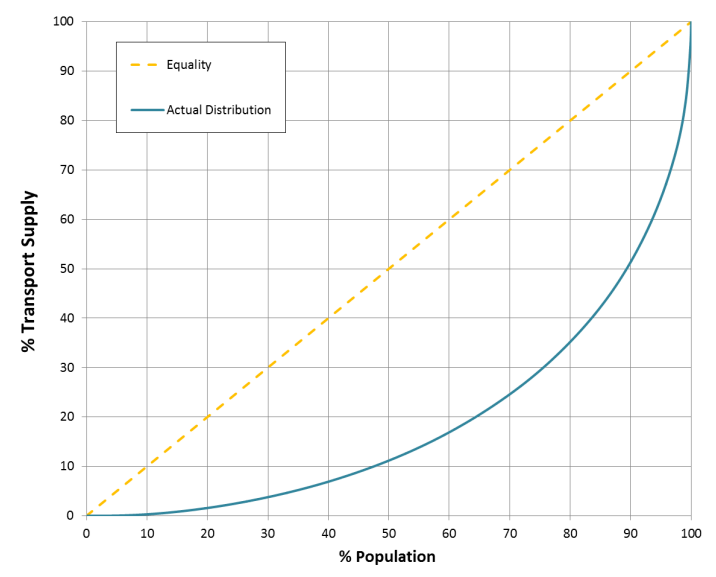

Fig. 2. Example Lorenz curve

Whereas the Lorenz curve presents a graphical representation of inequity across a population, the Gini coefficient is a single value based on the area between the line of equality in a perfectly equal distribution and the Lorenz curve representing the actual distribution (Delbosc and Currie, 2011b). The closer the Lorenz curve is to the line of equality the more equal the distribution is and the smaller the area enclosed between the two lines, and therefore smaller Gini coefficients represent more equal distributions. The equation used to calculate the Gini coefficient in this study follows that in Delbosc and Currie (2011b):

$$
G_{1}=1-\sum_{K=1}^{n}\left(X_{k}-X_{k-1}\right)\left(Y_{k}+Y_{k-1}\right)
$$

where $X_{k}$ is the cumulated proportion of the population variable, for $\mathrm{k}=0, \ldots, \mathrm{n}$, with $\mathrm{X}_{0}=0$, $\mathrm{X}_{\mathrm{n}}=1$ and $\mathrm{Y}_{\mathrm{k}}$ is the cumulated proportion of the public transport service variable, for $\mathrm{k}=0, \ldots$ , $\mathrm{n}$, with $\mathrm{Y}_{0}=0, \mathrm{Y}_{\mathrm{n}}=1$. It should be noted that there are many equations that can be used to calculate the Gini coefficient, and the one used here simplifies the calculation in that it approximates the area underneath a Lorenz curve as the sum of a series of trapezoids, which is considered adequate for the purposes of this study.

\section{Results}

\subsection{Supply Index and NSIPA}

The public transport NSIPA values calculated for each city are shown in Table 1 and Fig. 3. The NSIPA values have been classified into six groups and the total number of SA1s within each class was calculated for each broad area (inner, middle and outer) within each city, in addition to the number of zero transport supply and zero population SA1s. It was necessary to separate zero population areas into their own group as these areas will always have an NSIPA value of zero even if they receive a high amount of public transport, whereas zero supply areas represent those where transport supply is not present at all. The maps in Fig. 3-4 are both shown to the same scale in order to emphasise the geographical differences between Perth and Sydney. Examining these results, several observations can be made:

- 22,512 residents in greater Perth, or $1.3 \%$ of the population, receive zero supply of public transport. Within greater Sydney this figure is 21,537 residents, or $0.5 \%$ of the total population. In both cases the majority of the zero-supply population resides in the outer areas of the city.

- The two lowest NSIPA categories $(<20,20-40)$ account for $82.0 \%$ of greater Perth's population. In Sydney the two lowest categories account for only $42.0 \%$ of the total population. In both cases these populations are located mainly in the middle and outer 
areas of the city. However, $42.5 \%$ of Perth's inner city SA1s also fall into these two lowest categories, whereas only 12.1\% of Sydney's inner Sydney's SA1s are in the two lowest categories.

- $1,545,450$ residents in greater Sydney (35.2\% of the population), a figure which is almost equivalent to the entire population of Perth, receive the highest NSIPA category of transport supply $(>100)$. In greater Perth this figure is dramatically lower, with only 54,827 residents, or $3.2 \%$ of the population, falling within the highest category. These populations reside predominantly in the inner areas of both cities.

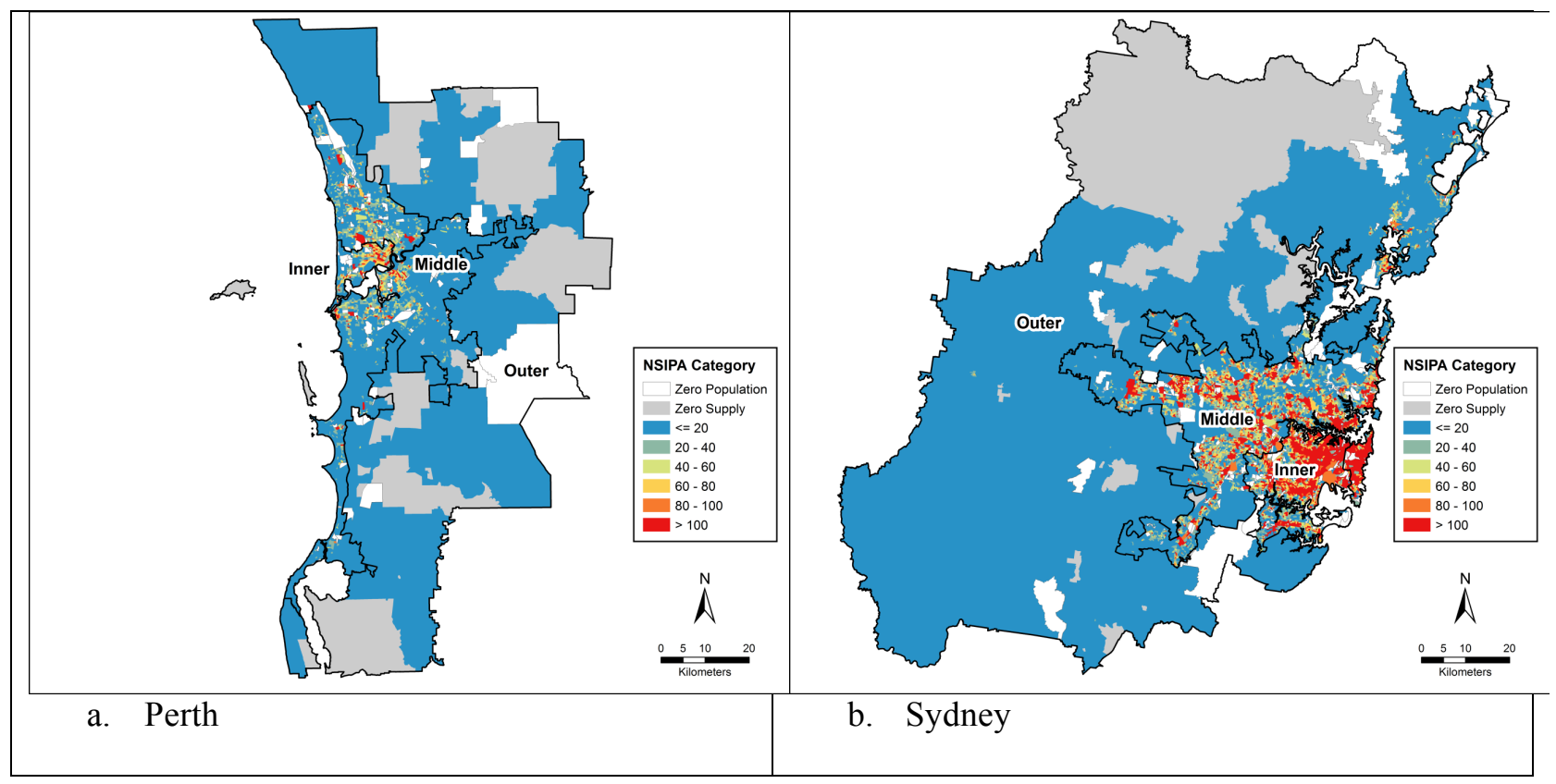

Fig. 3. Spatial distribution of NSIPA values across greater Perth and Sydney.

Table 1 NSIPA categories and population for greater Perth and Sydney.

\begin{tabular}{|c|c|c|c|c|c|c|}
\hline \multirow[b]{2}{*}{ NSIPA Category } & \multicolumn{3}{|l|}{ PERTH } & \multicolumn{3}{|c|}{ SYDNEY } \\
\hline & $\begin{array}{l}\text { Number } \\
\text { SA1s }\end{array}$ & ${ }^{o f}$ Population & \% Population & $\begin{array}{l}\text { Number } \\
\text { SA1s }\end{array}$ & ${ }^{\text {of }}$ Population & \% Population \\
\hline Zero Population & 108 & 0 & $0.00 \%$ & 274 & 0 & $0.00 \%$ \\
\hline Zero Supply & 65 & 22512 & $1.30 \%$ & 66 & 21537 & $0.50 \%$ \\
\hline$<20$ & 2364 & 1107628 & $64.10 \%$ & 2639 & 1170424 & $26.70 \%$ \\
\hline $20-40$ & 761 & 310137 & $17.90 \%$ & 1497 & 673241 & $15.30 \%$ \\
\hline $40-60$ & 352 & 133793 & $7.70 \%$ & 1053 & 447976 & $10.20 \%$ \\
\hline $60-80$ & 181 & 68687 & $4.00 \%$ & 789 & 324935 & $7.40 \%$ \\
\hline $80-100$ & 89 & 31281 & $1.80 \%$ & 542 & 208110 & $4.70 \%$ \\
\hline$>100$ & 174 & 54827 & $3.20 \%$ & 3985 & 1545450 & $35.20 \%$ \\
\hline Total & 4094 & 1728865 & $100.00 \%$ & 10845 & 4391673 & $100.00 \%$ \\
\hline
\end{tabular}

Table 2 summarises the supply index and NSIPA values that were calculated for each area (inner, middle, outer, total) of each city, as well as presenting some additional transport supply 
and population measurements for each area in order to allow for further comparison of the two cities. These have also been calculated with the aim of comparing them to a study undertaken by Currie (2010) in the Australian city of Melbourne. The results presented in Table 2 show that:

- SA1s in Perth have on average a slightly higher number of public transport locations than Sydney, given the average area of SA1s in Sydney is around 2 times smaller than Perth. However, there are considerably more average weekly service arrivals at these stops in Sydney than in Perth.

- Inner city areas in both cities are very well covered by public transport walking catchments, with an average of $98 \%$ of the areas of inner city SA1s receiving coverage. However, outer Sydney areas receive much better public transport coverage than outer Perth areas (67\% average coverage as opposed to $38 \%$ average coverage).

- Sydney has much higher average supply index scores for all areas within the city. This is due to the higher number of overall service arrivals in Sydney, particularly in the inner city. The average supply index value calculated here for inner Sydney (12094.2) is comparable to that calculated for inner Melbourne (10922.7) by Currie (2010). Therefore, Sydney has better overall public transport supply than Perth.

- Average NSIPA values obtained for all areas of Sydney are dramatically higher than those for Perth. This reflects the higher overall service levels within Sydney. It is also due to the way NSIPA is calculated, with Sydney having SA1s with considerably smaller areas across all parts of the city, particularly in the inner city which contains transport stops with very high numbers of services arrivals and overlapping walking catchments that supply transport to several SA1s.

Table 2 Measurements of public transport supply and NSIPA values for areas within each city.

\begin{tabular}{|c|c|c|c|c|c|c|c|c|}
\hline \multirow[b]{2}{*}{ Indicators } & \multicolumn{4}{|c|}{ PERTH } & \multicolumn{4}{|c|}{ SYDNEY } \\
\hline & Inner & Middle & Outer & Total & Inner & Middle & Outer & Total \\
\hline Number of SA1s & 379 & 3433 & 282 & 4094 & 2575 & 6967 & 1303 & 10845 \\
\hline $\begin{array}{l}\text { Total number of transport } \\
\text { stops }\end{array}$ & 1281 & 10348 & 851 & 12480 & 5286 & 17131 & 4502 & 26919 \\
\hline $\begin{array}{l}\text { Average number of stops in } \\
\text { each SA1 }\end{array}$ & 3.4 & 3 & 3 & 3 & 2.1 & 2.5 & 3.5 & 2.5 \\
\hline $\begin{array}{l}\text { Average number of services } \\
\text { per week per stop }\end{array}$ & 456 & 247 & 90 & 258 & 612 & 415 & 187 & 415 \\
\hline $\begin{array}{l}\text { Average total services per } \\
\text { week per SA1 }\end{array}$ & 1541 & 746 & 271 & 787 & 1257 & 1020 & 644 & 1031 \\
\hline $\begin{array}{l}\text { Average area of individual } \\
\text { SA1s }\left(\mathrm{km}^{2}\right)\end{array}$ & 0.24 & 0.43 & 17.2 & 1.57 & 0.11 & 0.25 & 7.93 & 1.14 \\
\hline Area of all SA1s $\left(\mathrm{km}^{2}\right)$ & 92.2 & 1472.6 & 4849.5 & 6414.3 & 293.9 & 1744.6 & 10332.7 & 12371.2 \\
\hline $\begin{array}{l}\text { Average proportion of each } \\
\text { SA1 covered by transport } \\
\text { stop walk catchment }\end{array}$ & $98 \%$ & $90 \%$ & $38 \%$ & $87 \%$ & $98 \%$ & $94 \%$ & $67 \%$ & $92 \%$ \\
\hline $\begin{array}{l}\text { Average proportion of all } \\
\text { SA1s covered by transport } \\
\text { stop walk catchment }\end{array}$ & $89 \%$ & $63 \%$ & $4 \%$ & $18 \%$ & $91 \%$ & $70 \%$ & $6 \%$ & $17 \%$ \\
\hline Average Supply Index (SI) & 4157.9 & 1569.2 & 258.7 & 1718.6 & 12094.2 & 4756.7 & 1154.1 & 6066.1 \\
\hline Population of all SA1s & 156371 & 1471211 & 101283 & 1728865 & 1051609 & 2857058 & 483006 & $\begin{array}{l}439167 \\
3\end{array}$ \\
\hline
\end{tabular}




\begin{tabular}{lllllllll}
$\begin{array}{l}\text { Average population of } \\
\text { individual SA1s }\end{array}$ & 413 & 429 & 359 & 422 & 408 & 410 & 371 & 405 \\
Average NSIPA value & 81.2 & 26.9 & 5 & 30.4 & 1260.8 & 216.7 & 20.7 & 441.1 \\
\hline
\end{tabular}

\subsection{Supply and Demand}

The number of SA1s in each of the public transport supply and demand categories was calculated for greater Perth and Sydney (Table 3), along with the percentage of the total population contained within each category. Additionally, the spatial distribution of these supply and demand categories are shown in Figs. 5 and 6. These results reveal that:

- The no-car household group is the least transport-disadvantaged of all three groups in terms of low supply - high demand areas, having the smallest number of such areas, and this result is consistent across both Perth and Sydney.

- The elderly resident group is the most transport-disadvantaged of all three groups for both cities, having the highest number of low supply - high demand areas. In Sydney the elderly-resident group also has a large number of high supply - low demand areas relative to the other groups. This may be due to the fact that the inner city of Sydney, which has some very high supply index values, has a lower elderly population compared to the middle and outer city areas.

- High supply - high demand or low supply - low demand areas, which can be thought of as areas where transport demand is being adequately met, are most common amongst the no-car household group, whereas the elderly group has the least number of areas where transport demand is being met. This holds true in both cities.

- In the case of both cities, areas of high supply and low demand for each of the three socio-economic groups are located almost exclusively in the inner and middle regions of the city. Conversely, areas of low supply and supply demand, where transport disadvantage is highest, occur primarily in the middle and outer regions of both cities.

Table 3 Supply and demand matrix for greater Perth and Sydney.

\begin{tabular}{|c|c|c|c|c|c|c|c|c|c|}
\hline \multicolumn{10}{|l|}{ Perth } \\
\hline \multirow[b]{2}{*}{ Class } & \multicolumn{3}{|c|}{ Elderly Population } & \multicolumn{3}{|c|}{ No Car Households } & \multicolumn{3}{|c|}{ Low Income Households } \\
\hline & SA1s & Pop. & \%Pop. & SA1s & Pop. & \%Pop. & SA1s & Pop. & \%Рop. \\
\hline $\mathrm{LS}-\mathrm{HD}$ & 236 & 87044 & 5 & 70 & 25206 & 1.5 & 162 & 60625 & 3.5 \\
\hline $\mathrm{HS}-\mathrm{LD}$ & 146 & 64880 & 3.8 & 98 & 30067 & 1.7 & 163 & 64851 & 3.8 \\
\hline $\begin{array}{l}\mathrm{HS}-\mathrm{HI} \\
\& \mathrm{LS}-\mathrm{LD}\end{array}$ & 641 & 273241 & 15.8 & 996 & 387865 & 22.4 & 721 & 303893 & 17.6 \\
\hline OTHER & 3071 & 1303700 & 75.4 & 2930 & 1285727 & 74.4 & 3048 & 1299496 & 75.2 \\
\hline Total & 4094 & 1728865 & 100 & 4094 & 1728865 & 100 & 4094 & 1728865 & 100 \\
\hline \multicolumn{10}{|l|}{ Sydney } \\
\hline & \multicolumn{3}{|c|}{ Elderly Population } & \multicolumn{3}{|c|}{ No Car Households } & \multicolumn{3}{|c|}{ Low Income Households } \\
\hline Class & SA1s & Pop. & \%Pop. & SA1s & Pop. & \%Pop. & SA1s & Pop. & \%Рор. \\
\hline $\mathrm{LS}-\mathrm{HD}$ & 674 & 256830 & 5.8 & 119 & 46654 & 1.1 & 491 & 186984 & 4.3 \\
\hline $\mathrm{HS}-\mathrm{LD}$ & 808 & 359780 & 8.2 & 141 & 35290 & 0.8 & 536 & 206842 & 4.7 \\
\hline $\begin{array}{l}\mathrm{HS}-\mathrm{HI} \\
\& \mathrm{LS}-\mathrm{LD}\end{array}$ & 1304 & 459139 & 10.5 & 3028 & 1207900 & 27.5 & 1635 & 610736 & 13.9 \\
\hline OTHER & 8059 & 3315924 & 75.5 & 7557 & 3101829 & 70.6 & 8183 & 3387111 & 77.1 \\
\hline Total & 10845 & 4391673 & 100 & 10845 & 4391673 & 100 & 10845 & 4391673 & 100 \\
\hline
\end{tabular}


As previously noted, this study only focused on the top and bottom quartiles of values in order to define low/high supply and low/high demand, and thus SA1s falling into the $2^{\text {nd }}$ and $3^{\text {rd }}$ quartiles of supply index values or percentage of elderly population/no car household/low income household values are represented by the class 'Other' in Tables 3 and Figure 4 and 5.

\subsection{Areas of Concern}

Areas of concern in terms of public transport disadvantage were defined as any SA1 with a low supply of public transport and a high demand for all of the three socioeconomic groups.

Areas of concern in Perth and Sydney are displayed in Figs. 4 and 5, and population statistics for these areas are presented in Table 4 . These results indicate that:

- The middle region of both cities contains the highest percentage of areas of concern, whereas the inner area contains the fewest. In the case of Perth, there are no areas of concern within the inner city area and instead these are concentrated almost entirely within the middle area of the city ( $87.4 \%$ of all areas of concern), whereas within Sydney the areas of concern are spread relatively evenly across the middle and outer areas.

- Although Perth has fewer overall areas of concern, there is a higher percentage of the entire city's population (0.63\%) living within these areas than in the case of Sydney, which has $0.52 \%$ of its total population living in areas of concern for public transport disadvantage. 


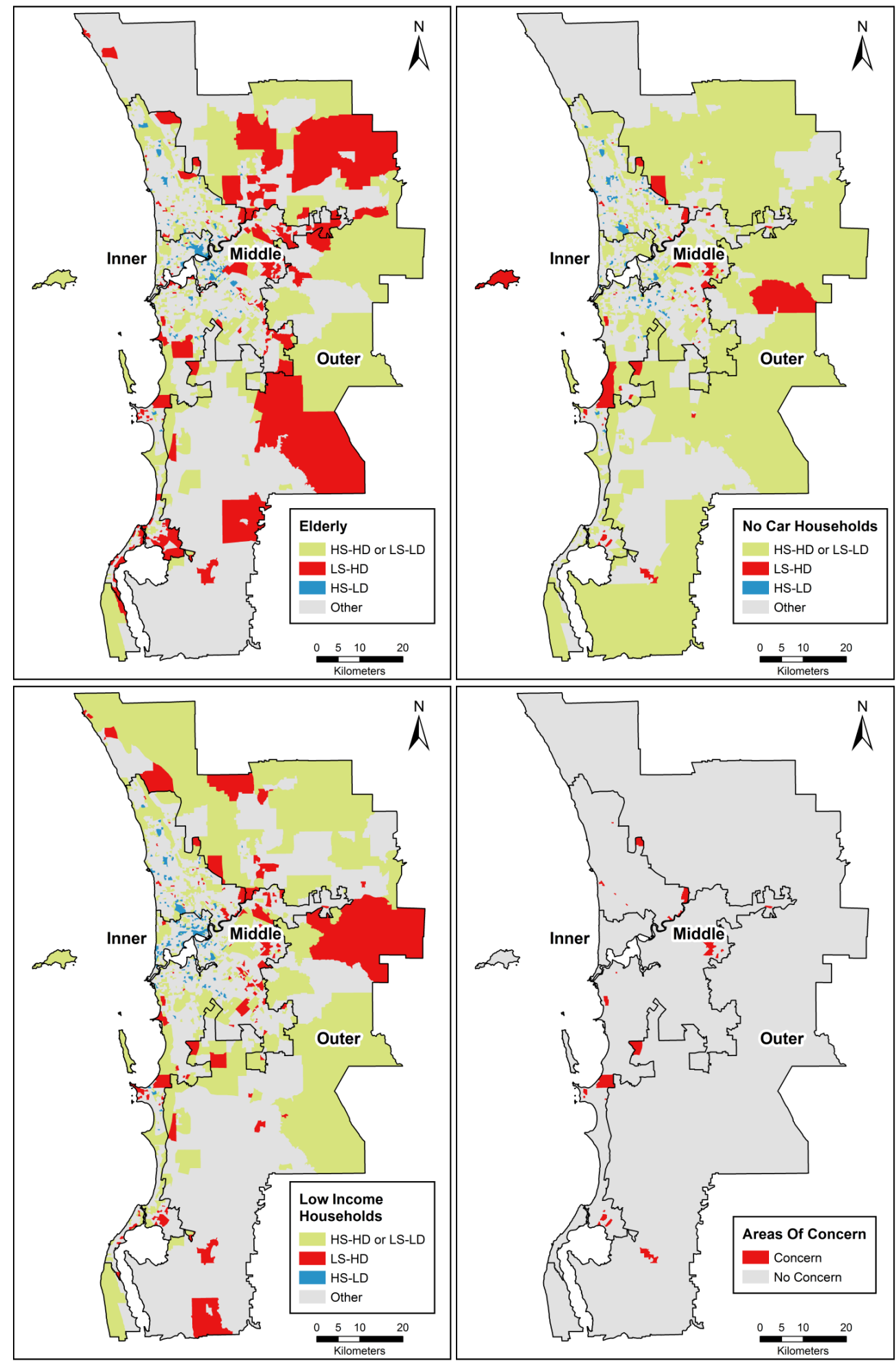

Fig.4. Areas of concern in greater Perth 


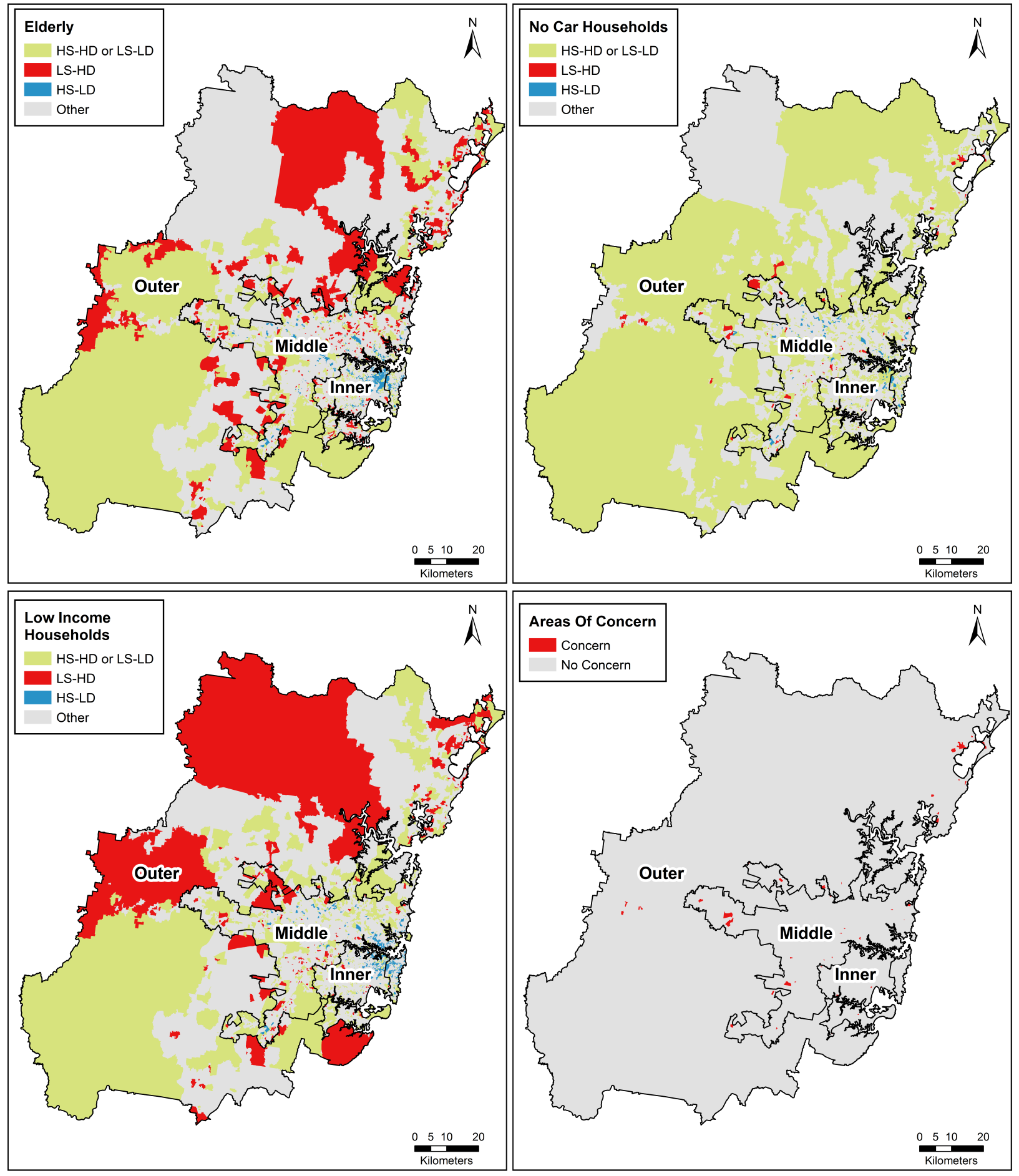

Fig.5. Areas of concern in greater Sydney

Table 4 Affected population residing within areas of concern

\begin{tabular}{|c|c|c|c|c|c|c|c|c|}
\hline \multirow[b]{2}{*}{ Socioeconomic Group } & \multicolumn{4}{|c|}{ PERTH } & \multicolumn{4}{|c|}{ SYDNEY } \\
\hline & Inner & Middle & Outer & Total & $\overline{\text { Inner }}$ & Middle & Outer & Total \\
\hline Number of SA1s & 0 & 25 & 4 & 29 & 4 & 29 & 26 & 59 \\
\hline Population & 0 & 9499 & 1366 & 10865 & 1143 & 11190 & 10539 & 22872 \\
\hline$\%$ Population & 0.0 & 87.4 & 12.6 & 100 & 5.0 & 48.9 & 46.1 & 100 \\
\hline$\%$ Total City Population & 0.0 & 0.55 & 0.08 & 0.63 & 0.03 & 0.25 & 0.24 & 0.52 \\
\hline
\end{tabular}




\subsection{Lorenz Curves and Gini Coefficients}

Lorenz curves were calculated for the total population and each of the three socio-demographic groups (elderly population, no-car households, low-income households) in each city using the supply index values calculated in the previous section. This was done for the greater city area in addition to the inner, middle and outer city areas. The Lorenz curves for greater Perth and Sydney are presented in Fig. 6. Additionally, the calculated Gini coefficients representing the difference between transport equity and the actual transport supply situation as defined by the Lorenz curve are shown for the three vulnerable transport groups within each city in Table 5 . Examining the Lorenz curves and Gini coefficients indicates that:

- No-car households receive the most equal supply of public transport across all areas of both Perth and Sydney compared to elderly population and low-income groups. This group also receives a more equal supply than the total population in all cases, and this difference is most profound in Sydney.

- Elderly residents receive the least equal supply across all areas of both Perth and Sydney compared to low-income and no-car households, with the exception of outer Sydney where the difference between the total population $(\mathrm{G}=0.63)$ and the elderly population $(\mathrm{G}=0.62)$ is only minor.

- Greater Perth has a more equal distribution of public transport across all three groups than greater Sydney, and this is also reflected when comparing the inner and middle areas of the cities.

- For Sydney, equity within the outer city is comparable to equity within other areas of the city for all three groups, and the outer city doesn't always contain the least equal distribution of public transport. However, the outer area of Perth contains the least equal distribution of transport for all groups by a wide margin, likely due to the poor transport walking catchment coverage of SA1s in this area, as indicated in Table 2.

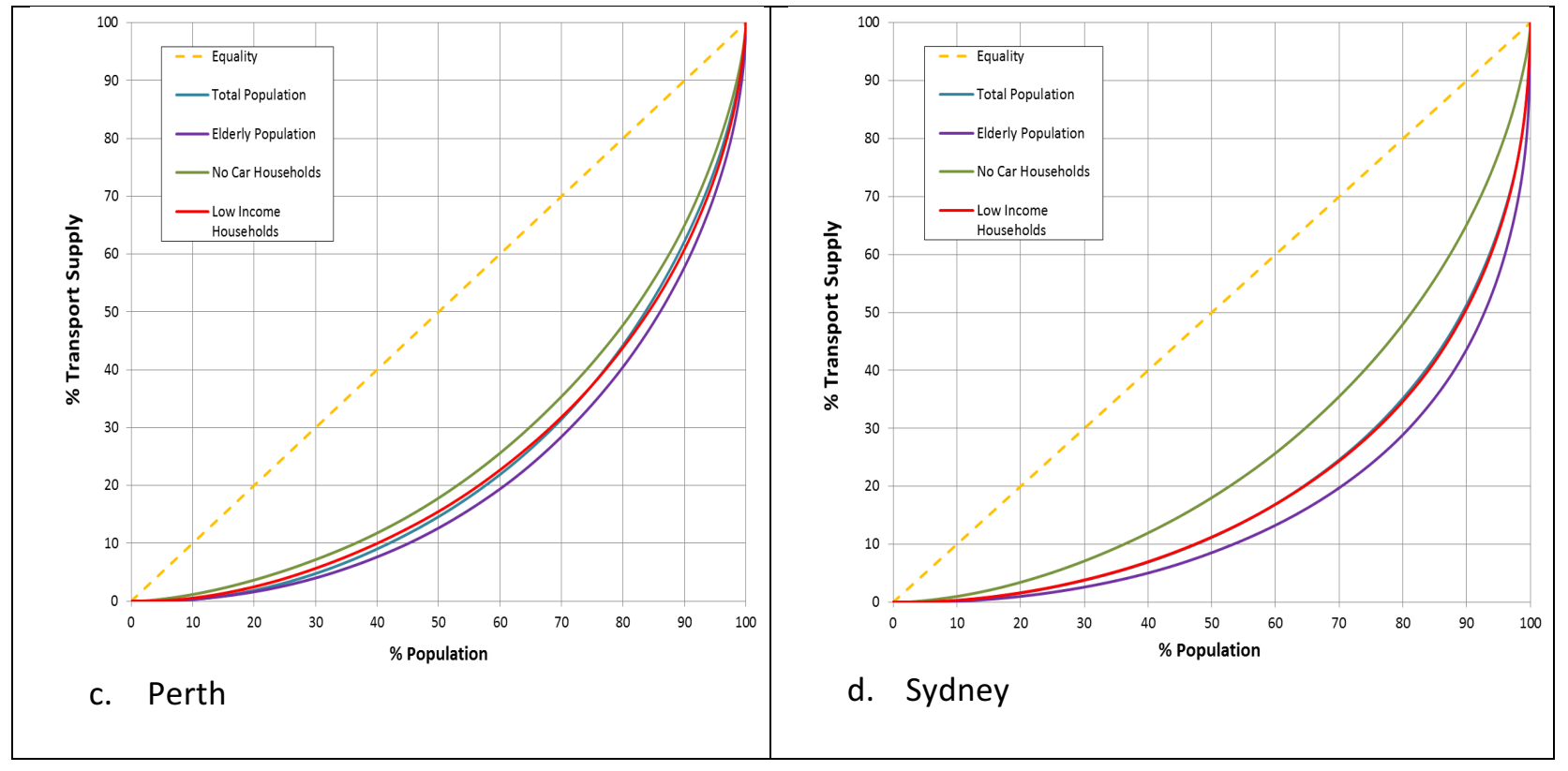

Fig. 6. Lorenz curve of transport supply for greater Perth and Sydney 
Table 5 Gini coefficients across the three socioeconomic groups in all areas of Sydney and Perth.

\begin{tabular}{|c|c|c|c|c|c|c|c|c|}
\hline \multirow[b]{2}{*}{ Socio-economic Group } & \multicolumn{4}{|l|}{ PERTH } & \multicolumn{4}{|c|}{ SYDNEY } \\
\hline & Greater & Inner & Middle & Outer & Greater & Inner & Middle & Outer \\
\hline Total Population & 0.53 & 0.47 & 0.49 & 0.77 & 0.62 & 0.59 & 0.55 & 0.63 \\
\hline Elderly & 0.57 & 0.6 & 0.53 & 0.86 & 0.68 & 0.69 & 0.6 & 0.62 \\
\hline No-Car Households & 0.48 & 0.42 & 0.48 & 0.74 & 0.48 & 0.45 & 0.47 & 0.54 \\
\hline Low-Income Households & 0.53 & 0.48 & 0.48 & 0.81 & 0.62 & 0.6 & 0.55 & 0.56 \\
\hline
\end{tabular}

\section{Policy Implications}

This paper compared the transport inequity of three cohorts between Perth and Sydney (see Figure 7). Basically, transport inequity depends on two dimensions: transport supply and demand. Demand is typically determined by the growth of jobs and employed residents, the concentration of jobs, and population and housing affordability. When transport supply more closely matches demand, transport equity is better. And, when demand is concentrated around public transport nodes rather than further away, transport equity is better. When more residents work locally, transport demand is lower. With less urban sprawl and better public transport mode share, transport equity is better. And, with better housing affordability and less displacement of low-income people, transport equity is better (Litman 2015). Table 6 summarises these factors by sectors. 


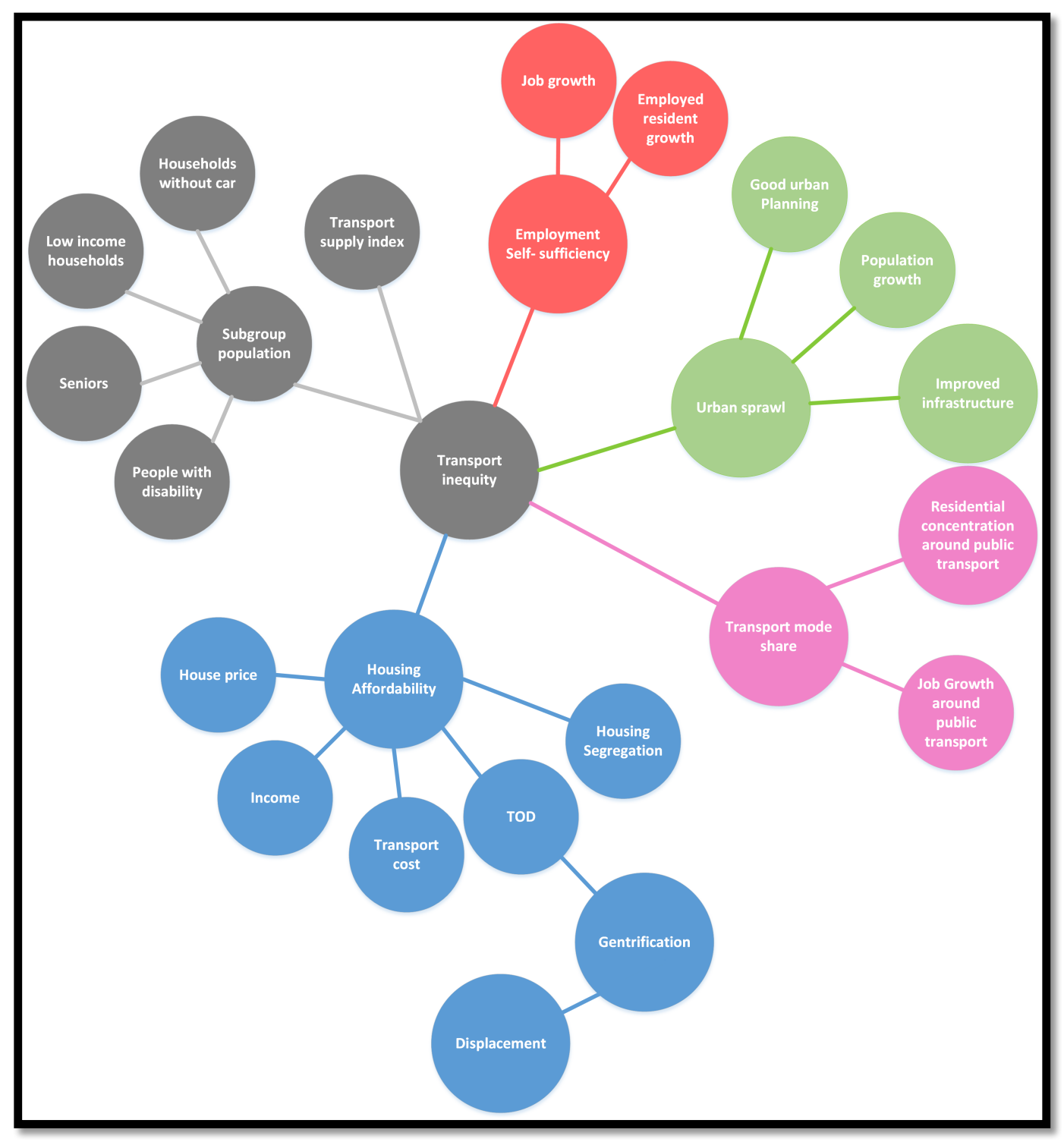

Fig. 7 A conceptual framework of transport inequity

Generally, public transport availability is more equal in the Perth inner and middle sectors than in the corresponding Sydney sectors. However, the public transport mode share was twice as high in Sydney (13.5 per cent) than in Perth (6.9 per cent) in 2011. This might suggest constraints, such as congestion, pushing car users to use public transport. For example, morning peak hour average road travel speed in 2006-07 was $35 \mathrm{~km} /$ hour in Sydney compared to $41 \mathrm{~km} /$ hour in Perth. The unit cost of congestion in Sydney was 8 cent $(\mathrm{c}) / \mathrm{km}$ (projected to be $12.3 \mathrm{c} / \mathrm{km}$ in 2020), while it was around $4.7 \mathrm{c} / \mathrm{km}$ in 2005 (projected to be $8.3 \mathrm{c} / \mathrm{km}$ in 2020) in Perth (Bureau of Transport and Regional Economics [BTRE] 2007). Both Sydney and Perth have strategic plans that focus on residential and job growth around public transport. Sydney has seen population concentration around train stations, with 42 per cent of residential development being centred around public transit nodes between 2000-01 and 2009-10, along with a decline in the concentration of employment around stations (-1.3 per cent within 1000 metres from 2001 to 2006). Job growth tends to be in outer suburban industrial areas and nonrail-connected specialised centres. Perth's population has become slightly less concentrated around transport stations, while a moderate increase of employment concentration occurred (BITRE 2010, 2012a). Therefore, the policies of both cities have had mixed results in improving transport inequity. 
No-car households receive the most equal supply of public transport across all areas of both Perth and Sydney compared to elderly population and low-income groups. This group also receives a more equal supply than the total population in all cases, and this difference is most profound in Sydney. In contrast, elderly residents receive the least equal supply across all areas of both Perth and Sydney compared to low-income and no-car households, with the exception of outer Sydney. This might due to residential location self-selection (Scheiner 2010, Bohte, Maat, and van Wee 2009, Cao, Mokhtarian, and Handy 2009). No-car households may choose to live in areas with accessible public transport (PT) in order to use PT more (Cao, Mokhtarian, and Handy 2009). While for the elderly, they tend to move for amenities, to downsize their house or to receive assistance from others (Meyer and Speare Jr 1985). We mapped the spatial distribution of no-car households and the elderly in Perth (See Figure 8). The elderly distributed more dispersedly away from public transport catchment areas than no-car households.
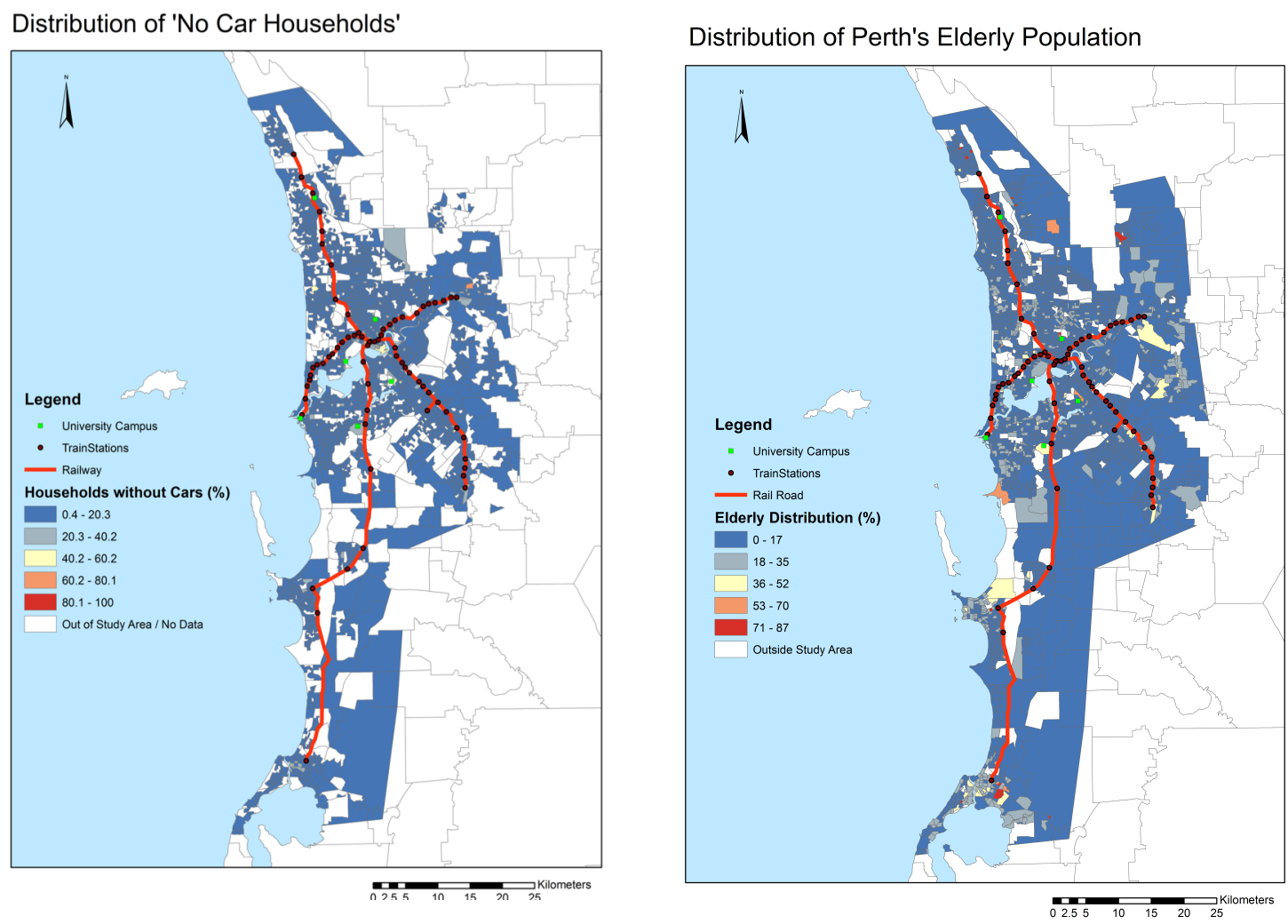

Figure 8 The spatial distribution of No-car households and the elderly population

Perth's outer sector has higher transport inequity (0.77) than Sydney (0.63), based on the Gini coefficients calculated in this study. This could be due to many factors, such as transport supply, employment self-sufficiency, residential self-selection and urban sprawl. In 2011, the average population of individual SA1s in the outer sector of Perth was 359 people, while this figure was 371 in Sydney. The average Supply Index (SI) in Sydney's outer sector is 4.5 times higher than Perth (1154.1 compared to 258.7). Sydney had several strategic reviews of public transport supply in the outer sector (the NSW Government's 2005-2012 Bus Reform strategies) and took actions in improving provision of bus services for dispersed employment (Transport for NSW 2012, NSW Transport \& Infrastructure 2013). For example, bus service kilometres in Sydney increased by $8.7 \%$ in $2010 / 11$ because NSW introduced integrated network plans, new growth buses, Metrobuses and free Shuttle bus services (Boxall, Cox, and 
Draper 2013). Bus patronage increased by 43\% from 1999 to 2009 in Perth, with around 27\% of the increase due to an expansion of the bus system (Department of Transport 2011 p. 14). According to Department of Infrastructure and Regional Development (2015), high population grows on the urban fringes, while knowledge-based jobs are tending to move inwards, seeking agglomeration. This results spatial divide between jobs and residents becomes wider and jobs to population ratios in outer areas are struggling. Table 6 shows the growth of different industries across these two cities between 2001 and 2011 (Bureau of Infrastructure Transport and Regional Economics (BITRE) 2013). Retail trade is the fastest growing industry in the Perth outer sector and it is health and community services for the Sydney outer sector.

Self-sufficiency ratios reflect the balance between employed residents and jobs. Lower values indicate a higher imbalance between these two factors, meaning more employed residents must commute further. According to the Bureau of Infrastructure Transport and Regional Economics (BITRE) (2013), Sydney had slightly higher employment self-sufficiency ratios in 2006 for the outer sector (0.63) than Perth (0.52), and lower employment self-sufficiency ratios for the inner sector (1.68) than Perth (2.14). However, Perth has experienced a growth of self-sufficiency in employment for the outer sector from 0.51 (2001) to 0.52 (2011) percentage. For Sydney, it decreased from 0.62 (2001) to 0.61 (2011) percentage. In addition, the population growth of the outer sector contributed to $46 \%$ of Sydney's growth and $69 \%$ of Perth's growth (Bureau of Infrastructure Transport and Regional Economics (BITRE) 2013). This demonstrates that Sydney has had more success in limiting urban sprawl, increasing housing density and decreasing transport costs than Perth.

According to NATSEM (2011), housing affordability in Perth is much better than Sydney (see Table 6). All three sectors in Sydney were found to be in the severely unaffordable range. Except for the inner sector in this range, Perth middle and outer sectors are in slightly better position. Sydney's inner sector has the most expensive property market in Australia with a median price of $\$ 685,000$, although Sydney's middle sector median price $(\$ 401,000)$ was lower than in Perth $(\$ 420,000)$. However, the disposable income in Perth's middle sector $(\$ 1,310)$ is $20 \%$ higher than Sydney $(\$ 1,045)$. Unaffordable housing in both cities may create gentrification, which means certain demographics, especially low-income households, may be priced out of public transport connected areas (Sanchez, Stolz, and Ma 2003). This will lead to a serious transport inequity problem. Currently, Perth's outer sector experiences this issue, with the low-income household Gini coefficient reaching 0.81 and the elderly population's Gini coefficient reaching 0.86. Transit-oriented development (TOD) is one of the major government policies used in Perth to promote land use and transport-integrated development (Bureau of Infrastructure Transport and Regional Economics (BITRE) 2013). This is a positive step, however TOD could encourage gentrification (Atkinson-Palombo and Kuby 2011). Therefore, further measures and strategies, such as flexible bus services, investment in high quality rail and bus links, decentralised of jobs from central cities (Dodson 2004, Burke, Li, and Dodson 2011), increasing residential density in new outer urban growth areas (Buxton and Scheurer 2007), and affordable and accessible housing (Litman 2015) could be applied to improve transport-related social exclusion issues in the outer sector of Perth. For Sydney, where the inner sector experienced the highest housing unaffordability and transport inequity for the elderly and low-income households, policies such as transport subsidies (Gannon and Liu 1997) to protect these populations can help (Infrastructure Australia 2015).

Table 6 Factors influencing transport inequity (Source: (Bureau of Infrastructure Transport and Regional Economics (BITRE) 2013, NATSEM 2011)) 


\begin{tabular}{|c|c|c|c|c|c|c|c|c|}
\hline \multirow[b]{2}{*}{ Factors } & \multicolumn{4}{|c|}{ PERTH } & \multicolumn{4}{|c|}{ SYDNEY } \\
\hline & \multicolumn{2}{|c|}{ Greater Inner } & \multirow[t]{2}{*}{ Middle } & \multirow[t]{2}{*}{ Outer } & \multicolumn{2}{|c|}{ Greater Inner } & \multirow[t]{2}{*}{ Middle } & \multirow[t]{2}{*}{ Outer } \\
\hline \multicolumn{5}{|c|}{ Housing Affordability, 2011} & & & & \\
\hline $\begin{array}{l}\text { Affordability } \\
\text { ratio }\end{array}$ & & 7.7 & 6.1 & 6.3 & & 9.7 & 7.4 & 8.1 \\
\hline Price Growth & & $179.10 \%$ & $268.40 \%$ & $215.80 \%$ & & $75.60 \%$ & $88.50 \%$ & $91.80 \%$ \\
\hline $\begin{array}{l}\text { Disposable } \\
\text { income }\end{array}$ & & $\$ 1,276$ & $\$ 1,310$ & $\$ 1,274$ & & $\$ 1,351$ & $\$ 1,045$ & $\$ 1,137$ \\
\hline $\begin{array}{l}\text { Median } \\
\text { house price }\end{array}$ & & $\$ 515,000$ & $\$ 420,000$ & $\$ 420,000$ & & $\$ 685,000$ & $\$ 401,000$ & $\$ 479,500$ \\
\hline \multicolumn{9}{|c|}{ Employment self-sufficiency, 2011} \\
\hline $\begin{array}{l}\text { Employment } \\
\text { self- } \\
\text { sufficiency } \\
\text { ratios }\end{array}$ & 0.88 & 2.14 & 0.86 & 0.52 & 0.91 & 1.68 & 0.93 & 0.63 \\
\hline \multicolumn{9}{|c|}{ Employment projections (per cent), 2006-2031 } \\
\hline $\begin{array}{l}\text { Share } \\
\text { growth }\end{array}$ & $f 100$ & 26 & 19 & 55 & 100 & 28 & 25 & 48 \\
\hline $\begin{array}{l}\text { Average } \\
\text { annual } \\
\text { growth }\end{array}$ & 1.7 & 1.2 & 1.2 & 2.7 & 1.4 & 1.1 & 1.2 & 1.7 \\
\hline \multicolumn{9}{|c|}{ The growth of different industries between 2001 and 2011} \\
\hline $\begin{array}{l}\text { Types of jol } \\
\text { growth }\end{array}$ & & $\begin{array}{c}\text { Property } \\
\text { and } \\
\text { business } \\
\text { services }\end{array}$ & Construction & $\begin{array}{l}\text { Retail } \\
\text { trade }\end{array}$ & & $\begin{array}{c}\text { Finance } \\
\text { and } \\
\text { insurance }\end{array}$ & $\begin{array}{l}\text { Health and } \\
\text { community } \\
\text { services }\end{array}$ & $\begin{array}{l}\text { Health and } \\
\text { community } \\
\text { services }\end{array}$ \\
\hline \multicolumn{9}{|c|}{ Transport mode share for journey to work by sector of residence (per cent), 2006} \\
\hline Car & 73.4 & 49.1 & 70.6 & 79.7 & 66.5 & 46.7 & 63.9 & 74.9 \\
\hline $\begin{array}{l}\text { Other privat } \\
\text { vehicles }\end{array}$ & & 1.7 & 2.3 & 3.7 & 2.1 & 1.3 & 1.7 & 2.5 \\
\hline $\begin{array}{l}\text { Public } \\
\text { transport }\end{array}$ & 13.5 & 20.6 & 17.1 & 8.3 & 20.7 & 32.4 & 25 & 14.3 \\
\hline Cycling & 1.1 & 3.1 & 1.3 & 0.6 & 0.6 & 1.5 & 0.5 & 0.4 \\
\hline Walking & 3.5 & 19.4 & 3 & 2 & 4.7 & 11.8 & 4.1 & 2.6 \\
\hline Other modes & 1.2 & 1.4 & 1.1 & 1.2 & 1 & 1.3 & 0.9 & 0.9 \\
\hline $\begin{array}{l}\text { Worked a } \\
\text { home }\end{array}$ & at 4.5 & 4.7 & 4.6 & 4.4 & 4.4 & 5.1 & 4 & 4.4 \\
\hline
\end{tabular}

\section{Concluding remarks}

This study investigated transport-related social exclusion from a multi-dimensional view, considering different urban development stages and spatial aggregation levels, a variety of factors influencing transport-related social exclusion, and different demographics. Sydney is a much more developed urban environment than Perth. For both cities, the inner sector is at a more advanced development stage than the middle sector, as is the middle sector compared to the outer sector. At the sector level in Perth, the more developed a region (i.e., the inner versus outer sector), the better is the spread of services. For Sydney, the middle sector outperformed 
the inner sector in terms of transport equity. At the city level, Perth has a more equal spread of services but a lower number of services than Sydney.

Three insights were derived from our analyses to explain this phenomenon:

- Housing affordability is one of the major causes of transport inequity;

- Good urban planning practice, such as anti-urban sprawl remedies and integrated transport services (e.g very well connected rail-bus links) could be good options for managing transport inequity in the less developed regions, such as the outer sector;

- High residential concentration and job concentration around transit areas would significantly improve transport inequity.

- Policies should be in place to provide better transport services to the low income and seniors in the Perth outer sector.

- For Sydney, gentrification in the inner sector may start to be a serious problem.

- It would seem sensible for policy makers to pay closer attention to the impact of urban structure and accessibility on affordable housing and job opportunities available to lowincome households in order to ensure sustainable transport integrated land use development.

This paper hasn't considered possible physical disabilities within the cohorts (although age is a surrogate), financial costs of public transport, neighbourhood services, or walkability. For example, seniors may not choose to live in a neighbourhood with good public transport services if the area lacks good sidewalks and has heavy vehicle traffic, which makes street crossing difficult. Similarly, lower-income residents may find transit fares difficult to afford despite other attractive feature of an area. Further research will be conducted to address these limitations in the future.

In addition, Transport inequity in this paper is viewed as all transport users' rights (society acceptance), deserts (person's ability or virtue) and needs (person's requirement) ought to be valued the same, irrespective of their income, car ownership, and age (Khisty 1996, Stopher and Stanley 2014). More specifically, public transport services should be distributed equally to users, irrespective of their income, car ownership and age. So it is a relative equity perspective. An argument to this perspective is that whether absolute supply is more important than relative equity (Stopher and Stanley 2014). In other words, a high level of transport supply is valued higher than equal distribution of transport supply among population, especially vulnerable population. In the future, we will develop a theory of sufficient transport to understand the underlying principle in balancing relative equity and absolute supply. 


\section{Reference}

Alpkokin, Pelin. 2012. "Historical and critical review of spatial and transport planning in the Netherlands." Land Use Policy 29 (3):536-547. doi: http://dx.doi.org/10.1016/j.landusepol.2011.09.007.

Atkinson-Palombo, Carol, and Michael J Kuby. 2011. "The geography of advance transit-oriented development in metropolitan Phoenix, Arizona, 2000-2007." Journal of Transport Geography 19 (2):189-199.

Australia Bureau of Statisitics (ABS). 2011. "Australian Statistical Geography Standard (ASGS): Volume 1 - Main Structure and Greater Capital City Statistical Areas." Accessed 23 September. http://www.abs.gov.au/ausstats/abs@.nsf/web+pages/Citing+ABS+Sources Journal\%2FNewsletter\%20articles.

BITRE. 2010. Population growth, jobs growth and commuting flows in Perth, Report 119,. BITRE, Canberra.

BITRE. 2012a. Population growth, jobs growth and commuting flows in Sydney, Report 132. BITRE, Canberra.

Blair, Neale, Julian Hine, and Syed Murtaza Asghar Bukhari. 2013. "Analysing the impact of network change on transport disadvantage: a GIS-based case study of Belfast." Journal of Transport Geography 31 (0):192-200. doi: http://dx.doi.org/10.1016/j.jtrangeo.2013.06.015.

Bocarejo, S., J. Pablo, H. Oviedo, and D. Ricardo. 2012. "Transport accessibility and social inequities: a tool for identification of mobility needs and evaluation of transport investments." Journal of Transport Geography 24 (0):142-154. doi: http://dx.doi.org/10.1016/j.jtrangeo.2011.12.004.

Bohte, Wendy, Kees Maat, and Bert van Wee. 2009. "Measuring attitudes in research on residential self - selection and travel behaviour: a review of theories and empirical research." Transport reviews 29 (3):325-357.

Boxall, Peter J, James Cox, and Simon Draper. 2013. "Review of fares for metropolitan and outer metropolitan bus services from January 2014:IPART's proposed fare setting approach ". Independent Pricing and Regulatory Tribunal of New South Wales Accessed 23 August. http://www.ipart.nsw.gov.au/files/sharedassets/website/trimholdingbay/issues_paper_review_of fares_for_metropolitan_and_outer_metropolitan_bus_services_from january 2014.pdf.

Bruinsma, Frank, and Piet Rietveld. 1993. "Urban agglomerations in European infrastructure networks." Urban Studies 30 (6):919-934.

Bureau of Infrastructure Transport and Regional Economics (BITRE). 2013. Population growth, jobs growth and commuting flows - a comparison of Australia's four largest cities, Report 142. Canberra ACT.

Bureau of Transport and Regional Economics [BTRE]. 2007. Estimating urban traffic and congestion cost trends for Australian cities, Working Paper 71. BTRE, Canberra ACT.

Burke, Matthew, Tiebei Li, and J Dodson. 2011. Planned Spatial Restructuring of Australian Cities: Are the transport benefits of employment decentralisation policies greater than those of transit-oriented development. In Urban Research Program: Griffith University

Buxton, Michael, and Jan Scheurer. 2007. "Density and outer urban development in Melbourne." Urban policy and research 25 (1):91-111.

Cao, Xinyu, Patricia L Mokhtarian, and Susan L Handy. 2009. "Examining the impacts of residential self - selection on travel behaviour: a focus on empirical findings." Transport Reviews 29 (3):359-395.

Church, A., and M. Frost. 1999. Transport and Social Exclusion. London Transport Planning.

Church, A., M. Frost, and K. Sullivan. 2000. "Transport and social exclusion in London." Transport Policy 7 (3):195-205. doi: http://dx.doi.org/10.1016/S0967-070X(00)00024-X.

Currie, Graham. 2010. "Quantifying spatial gaps in public transport supply based on social needs." Journal of Transport Geography 18 (1):31-41. doi: http://dx.doi.org/10.1016/j.jtrangeo.2008.12.002. 
Currie, Graham, and Alexa Delbosc. 2009. "Car ownership and low income on the urban fringeBenefit or hindrance." Proceedings of the 32nd Australasian Transport Research Forum.

Currie, Graham, and Alexa Delbosc. 2013. "Exploring trends in forced car ownership in Melbourne." Proceedings of the 36th Australasian Transport Research Forum (ATRF), Brisbane, Queensland, Australia.

Currie, Grahama, Tony Richardson, Paul Smyth, Dianne Vella-Brodrick, Julian Hine, Karen Lucas, Janet Stanley, Jenny Morris, Ray Kinnear, and John Stanley. 2010. "Investigating links between transport disadvantage, social exclusion and well-being in Melbourne - Updated results." Research in Transportation Economics 29 (1):287-295. doi: http://dx.doi.org/10.1016/j.retrec.2010.07.036.

De Vos, Jonas, and Frank Witlox. 2013. "Transportation policy as spatial planning tool; reducing urban sprawl by increasing travel costs and clustering infrastructure and public transportation." Journal of Transport Geography 33 (0):117-125. doi: http://dx.doi.org/10.1016/j.jtrangeo.2013.09.014.

Delbosc, Alexa, and Graham Currie. 2011. "Using Lorenz curves to assess public transport equity." Journal of Transport Geography 19 (6):1252-1259.

Department of Infrastructure and Regional Development. 2015. "State of Australian Cities 20142015." Commonwealth of Australia Accessed 28 August. https://infrastructure.gov.au/infrastructure/pab/soac/.

Department of Transport. 2011. Public Transport for Perth in 2031: Mapping out the future for Perth public transport network. Perth: Department of Transport.

Di Ciommo, Floridea, Julio Comendador, María Eugenia López-Lambas, Elisabetta Cherchi, and Juan de Dios Ortúzar. 2014. "Exploring the role of social capital influence variables on travel behaviour." Transportation Research Part A: Policy and Practice 68 (0):46-55. doi: http://dx.doi.org/10.1016/j.tra.2014.08.018.

Diener, Ed. 2000. "Subjective well-being: The science of happiness and a proposal for a national index." American psychologist 55 (1):34.

Dodson, Jago Robert. 2004. "Is there a spatial mismatch between housing affordability and employment opportunity in Melbourne?" the State of Australian Cities Conference, Parramatta, Sydney, 3-5, December.

Fan, Yingling, Andrew E. Guthrie, and David M. Levinson. 2012. "Impact of light rail implementation on labor market accessibility: A transportation equity perspective." Journal of Transport and Land Use 5 (3). doi: 10.5198/jtlu.v5i3.240.

Gaffron, Philine. 2012. "Urban transport, environmental justice and human daily activity patterns." Transport Policy 20 (0):114-127. doi: http://dx.doi.org/10.1016/j.tranpol.2012.01.011.

Gannon, Colin A, and Zhi Liu. 1997. Poverty and transport. World Bank Washington, DC.

Granovetter, Mark. 1985. "Economic Action and Social Structure: The Problem of Embeddedness." American Journal of Sociology 91 (3):481-510. doi: doi:10.1086/228311.

Infrastructure Australia. 2015. "Australian Infrastructure Audit Report Vol 1." Accessed 28 August. http://www.infrastructureaustralia.gov.au/policy-publications/publications/files/AustralianInfrastructure-Audit-Volume-1.pdf.

Jones, Peter, and Karen Lucas. 2012. "The social consequences of transport decision-making: clarifying concepts, synthesising knowledge and assessing implications." Journal of transport geography 21:4-16.

Kaplan, Sigal, Dmitrijs Popoks, Carlo Giacomo Prato, and Avishai Ceder. 2014. "Using connectivity for measuring equity in transit provision." Journal of Transport Geography 37 (0):82-92. doi: http://dx.doi.org/10.1016/j.jtrangeo.2014.04.016.

Khisty, C.J. 1996. "Operationalizing concepts of equity for public project investments." Transportation Research Record 1559:94-99.

Litman, Todd. 2014. Evaluating transportation equity: Victoria Transport Policy Institute.

Litman, Todd. 2015. Affordable-Accessible Housing In A Dynamic City. Victoria Transport Policy Institute.

Liu, Shiyong, Konstantinos P. Triantis, and Sudipta Sarangi. 2010. "A framework for evaluating the dynamic impacts of a congestion pricing policy for a transportation socioeconomic system." 
Transportation Research Part A: Policy and Practice 44 (8):596-608. doi: http://dx.doi.org/10.1016/j.tra.2010.04.001.

Liu, Yafei, Martin Dijst, and Stan Geertman. 2015. "Residential segregation and well-being inequality over time: A study on the local and migrant elderly people in Shanghai." Cities 49:1-13. doi: http://dx.doi.org/10.1016/j.cities.2015.06.012.

Lucas, Karen. 2006. "Providing transport for social inclusion within a framework for environmental justice in the UK." Transportation Research Part A: Policy and Practice 40 (10):801-809. doi: http://dx.doi.org/10.1016/j.tra.2005.12.005.

Lucas, Karen. 2012. "Transport and social exclusion: Where are we now?" Transport Policy 20 (0):105-113. doi: http://dx.doi.org/10.1016/j.tranpol.2012.01.013.

Lucas, Karen, Sophie Tyler, and Georgina Christodoulou. 2009. "Assessing the 'value' of new transport initiatives in deprived neighbourhoods in the UK." Transport Policy 16 (3):115122. doi: http://dx.doi.org/10.1016/j.tranpol.2009.02.004.

Lucas, Karen, Bert van Wee, and Kees Maat. 2016. "A method to evaluate equitable accessibility: combining ethical theories and accessibility-based approaches." Transportation 43 (3):473490. doi: 10.1007/s11116-015-9585-2.

Manaugh, K., and A. El-Geneidy. 2012. "Who benefits from new transportation infrastructure? Using accessibility measures to evaluate social equity in transit provision." Accessibility and Transport Planning: Challenges for Europe and North America:1035-1053.

Masser, Ian, Ove Svidén, and Michael Wegener. 1992. "From growth to equity and sustainability." Futures 24 (6):539-558. doi: http://dx.doi.org/10.1016/0016-3287(92)90116-W.

McMillan, David W, and David M Chavis. 1986. "Sense of community: A definition and theory." Journal of community psychology 14 (1):6-23.

Meyer, Judith W, and Alden Speare Jr. 1985. "Distinctively elderly mobility: Types and determinants." Economic Geography 61 (1):79-88.

Miller, Harvey J. 2006. "Social exclusion in space and time." AXHAUSEN KW Moving through nets: The Physical and Social Dimensions of Travel. Selected papers from the 10th International Conference of Travel Behaviour Research H. Elsevier Science Publishing Company.

Mishra, Sabyasachee, Timothy F Welch, and Manoj K Jha. 2012. "Performance indicators for public transit connectivity in multi-modal transportation networks." Transportation Research Part A: Policy and Practice 46 (7):1066-1085.

NATSEM. 2011. The Great Australian Dream - Just a Dream? Housing affordability trends for Australia and our largest 25 cities.

NSW Transport \& Infrastructure. 2013. Bus priority: Faster travel times for buses. Chippendale NSW: NSW Transport \& Infrastructure.

Páez, Antonio, Ruben Gertes Mercado, Steven Farber, Catherine Morency, and Matthew Roorda. 2010. "Relative accessibility deprivation indicators for urban settings: definitions and application to food deserts in Montreal." Urban Studies 47 (7):1415-1438.

Preston, John, and Fiona Rajé. 2007. "Accessibility, mobility and transport-related social exclusion." Journal of Transport Geography 15 (3):151-160.

Rawls, John. 1971. A Theory of Justice. Edited by Original ed. Cambridge, Mass: Belknap Press of Harvard University Press.

Ricciardi, Anthony Michael, Jianhong Cecilia Xia, and Graham Currie. 2015. "Exploring public transport equity between separate disadvantaged cohorts: a case study in Perth, Australia." Journal of Transport Geography 43:111-122.

Sanchez, Thomas W, Rich Stolz, and Jacinta S Ma. 2003. Moving to equity: Addressing inequitable effects of transportation policies on minorities. The Civil Rights Project at Harvard University, Cambridge, MA

Scheiner, Joachim. 2010. "Social inequalities in travel behaviour: trip distances in the context of residential self-selection and lifestyles." Journal of Transport Geography 18 (6):679-690.

Schwanen, Tim, Karen Lucas, Nihan Akyelken, Diego Cisternas Solsona, Juan-Antonio Carrasco, and Tijs Neutens. 2015. "Rethinking the links between social exclusion and transport 
disadvantage through the lens of social capital." Transportation Research Part A: Policy and Practice 74:123-135. doi: http://dx.doi.org/10.1016/j.tra.2015.02.012.

Sen, Amartya. 1981. Poverty and famines: an essay on entitlement and deprivation: Oxford University Press.

Sen, Amartya K. 1997. "From income inequality to economic inequality." Southern Economic Journal 64 (2):384-401.

Shergold, Ian, and Graham Parkhurst. 2012. "Transport-related social exclusion amongst older people in rural Southwest England and Wales." Journal of Rural Studies 28 (4):412-421. doi: http://dx.doi.org/10.1016/j.jrurstud.2012.01.010.

Social Exclusion Unit. 2001. Preventing social exclusion: Cabinet Office London.

Stanley, Janet, John Stanley, Dianne Vella-Brodrick, and Graham Currie. 2010. "The place of transport in facilitating social inclusion via the mediating influence of social capital." Research in Transportation Economics 29 (1):280-286. doi: http://dx.doi.org/10.1016/j.retrec.2010.07.035.

Stanley, John K., David A. Hensher, Janet R. Stanley, and Dianne Vella-Brodrick. 2011. "Mobility, social exclusion and well-being: Exploring the links." Transportation Research Part A: Policy and Practice 45 (8):789-801. doi: http://dx.doi.org/10.1016/j.tra.2011.06.007.

Stopher, Peter, and John Stanley. 2014. Introduction to transport policy: a public policy view: Edward Elgar Publishing.

Transport for NSW. 2012. for NSW.

Vaughan, Laura. 2007. "The spatial syntax of urban segregation." Progress in Planning 67 (3):205294. doi: http://dx.doi.org/10.1016/j.progress.2007.03.001.

Viry, Gil. 2012. "Residential mobility and the spatial dispersion of personal networks: Effects on social support." Social Networks 34 (1):59-72. doi: http://dx.doi.org/10.1016/j.socnet.2011.07.003.

Welch, Timothy F. 2013. "Equity in transport: The distribution of transit access and connectivity among affordable housing units." Transport Policy 30 (0):283-293. doi: http://dx.doi.org/10.1016/j.tranpol.2013.09.020.

Welch, Timothy F., and Sabyasachee Mishra. 2013. "A measure of equity for public transit connectivity." Journal of Transport Geography 33 (0):29-41. doi: http://dx.doi.org/10.1016/j.jtrangeo.2013.09.007.

Zhao, Pengjun, Bin Lü, and Gert de Roo. 2011. "Impact of the jobs-housing balance on urban commuting in Beijing in the transformation era." Journal of Transport Geography 19 (1):5969. doi: http://dx.doi.org/10.1016/j.jtrangeo.2009.09.008. 